\title{
BACK-HOME TOURISM IN EXTREMADURA, SPAIN: SPENDING PATTERNS AND MOTIVATION
}

\author{
Marcelo Sánchez-Oro Sánchez* \\ Universidad de Extremadura \\ http://orcid.org/0000-0002-0837-9372
}

\begin{abstract}
"Back-home tourism", "Tourism of return" or also typified as "Countryman tourism" is a category little considered by experts, academics and legislators in rural development, however in the last decades it is gaining prominence and special benefits are attributed to the unpopulated rural areas of the south of Europe. This tourism returns to their roots, in many cases where they have a second home or where they can share the home of relatives or friends. This tourism seeks an imagined habitat based on personal experience where family life is essential to repeat the visit and it is characterized by a consumption practice with nuances different from generic rural tourism. In this paper we try to identify the consumption patterns and motivations of this segment of the tourism market.
\end{abstract}

Keywords: tourism; back-home tourism; tourism of return; sociology of tourism; rural tourism; tourists motivations.

\section{El turismo de retorno en Extremadura (España): pautas de consumo y motivación}

\section{RESUMEN}

El "turismo de vuelta a casa", el "turismo de retorno", es un tipo de "turismo rural" considerada por expertos, académicos y legisladores como importante en desarrollo rural, en especial, para las áreas rurales despobladas del sur de Europa. Se trata de un tipo de viajeros que vuelve a sus raíces, en muchos casos donde tienen una segunda vivienda o donde comparten casa con los familiares o amigos oriundos. Este turismo busca un hábitat imaginado, basado en experiencias personales donde la vida familiar es esencial para repetir la visita, y se caracteriza llevar a cabo prácticas que presenta matices diferenciales

Fecha de recepción: 22 de febrero de 2019

Fecha de aceptación: 31 de octubre de 2019

* Facultad de Empresa, Finanzas y Turismo. Universidad de Extremadura. Avda. Universidad, s/n. 10071 CÁCERES (España).E-mail: msanoro@unex.es 
respecto al clásico turismo rural. En este artículo tratamos de identificar los patrones y motivaciones de este segmento del mercado turístico.

Palabras clave: turismo; turismo paisano; turismo de retorno; sociología del turismo; turismo rural; motivaciones turísticas.

\section{INTRODUCTION}

Our interest for defining the touristic role of travelers comes from the works of Cohen (1972), which established a typology based on the degree of authenticity that tourists seek in their trips. ${ }^{1}$ Another axis in the delimitation of this role is the degree of alienation that tourists feel in their daily environment (the level of desire or motivation in their search for space, relaxation, quiet, and the search of nature). Pearce (1982) focused on these taxonomies when he established 14 categories of travelers called "tourists." Pearce's classification (1982) is based on the behavior developed by these travelers. He described 22 different kinds of behavior that he calls "roles." In this way, he delimits and explains what the touristic role is.

Accordingly, we can say that only a portion of the visitors, emigrants who come back to Extremadura, develop an "authentic" touristic role in their trips to the region. The key distinction is in the main reason they invoke to come to Extremadura. Given that the motivation is accepted as a core concept in the behavior of tourists and in the process of choosing their destination (Castaño 2005), in this paper, we will take it as the defining feature of the type of back-home traveler to sort out those individuals moved by tourism from those who came for other reasons.

In Olabuénaga's (1994) analysis of the types of tourism in Spain in the last decades of the 20th century, he identified three major tourism models: "sun and beach" (people looking only for the commodities offered in these fields), "wandering about" (tourism where the main motivation is visiting many different places), and "back-home tourism" (people who come back to the municipality of their own or ancestral origin to carry out touristic activities with family or friends). The latter represents $13.8 \%$ of Spanish tourists or $28.8 \%$ of tourists in Spain. In reference to this typology, Yagüe (2002) uses the denomination turista tradicional or "back-home tourist" for relatives of people who, in a given moment, had to leave their villages to earn their living somewhere else and settled there for good, but they keep coming back to their ancient village for holidays, either because they own a house there or to stay with family or friends. In their discussion of different kinds of tourism, Rubio and García (2005) use the term paisano ("countryman") to define those tourists who visit their home city or that of their ancestors but do not live in that place.

González (2008) discussed how back-home tourism is a typology that is not recognized in official statistics. Other authors such as Morales et al. (2009) analyzed "nostalgic tourism" as a kind of tourism that is made up of migrants who periodically return from their place of residence or work to their community of origin for short periods. Arcos (2011) considers that contemporary migrants have greater possibilities of mobility, and 
this explains how a new tourist type known as "tourism of roots" or "nostalgic tourism" has emerged. This refers to emigrants who come back to their area of origin on certain dates to visit their families and friends.

Rubio, Sánchez-Oro, and García (2013) point out through empirical evidence the characteristics that make up this type of tourist, the turista paisano or "countryman tourist." For many inland rural areas, this phenomenon is of the utmost importance because they constitute an invaluable source of income and social dynamism that otherwise would not exist. They talk about villages and regions that have been the place of family reference of the father and/or grandparents who emigrated in the 1970s.

For the present paper, both "countryman tourist" and "back-home tourist" are used to refer to the same type of tourist. ${ }^{2}$

The typology used in this paper is based on motivation as the core factor. Castaño (2005) focused on the great importance of motivation in the tourism framework because it allows for answering three essential questions of the tourist cycle: the reasons to travel (why), the specific choice of the destination (where), and the evaluation of the experience (satisfaction).

\section{METHOD}

The aim of this work is to study the behavior of back-home tourists in the places where they spend their holidays and to examine their spending patterns and levels of satisfaction from their touristic experience. We have already established the role of that kind of tourist. In this paper, we consider six hypotheses; three of them refer to the interactions between the role of tourism and a set of behavioral and motivational variables, and the other three relate to the adscriptive characteristics of the sample.

Hypothesis 1. Back-home tourists, according to their motivation, have a positive correlation with their spending and consumption patterns at their destination.

Hypothesis 2: Back-home tourists, according to their motivation, have a negative correlation with some aspects of their satisfaction about the services provided at their destination (education, health care, social services, cultural events).

Hypothesis 3 . The collective worldview (the vision they have of the rural world) does not affect the tourist's motivation to choose a given destination.

Hypothesis 4. Coming from a specific region has a positive correlation in countryman tourists' motivation. It is also the main explanatory factor of their behavior at the destination.

Hypothesis 5. The correlation between back-home tourists' motivation and demographic variables such as education level, age, or number of people travelling are significant but not relevant.

Hypothesis 6. The demographic variables sex and marital status do not intervene in the back-home tourist's motivation.

To test these hypotheses, we interviewed 480 people from Extremadura settled in Catalonia, Basque Country, Madrid, and Andalusia. The poll was addressed to the population living outside of Extremadura. To set up the minimal necessary size of the sample, we used information from the National Institute of Statistics (INE) about the 
number people from Extremadura who live outside and the places where they live. To draw the sample, we used data from the Municipal Poll from 2010 allocated by autonomous communities of residence.

The information was treated so that we could use it later in population units to be able to sort the data about population strata and the number of sample units matching each stratum. The application of the sampling methodology and its proportional allocation was made with a confidence level of $95 \%$ and the maximum tolerable error of $\pm 4.5 \%$. The size of the intended sample was 474 interviews, but ultimately we reached 480 . The questionnaires were applied through personal interview from February to June 2010. Of the 480 interviews, $12.5 \%$ were proposed to people from Extremadura settled in Andalusia, $29.17 \%$ in Catalonia, $46.88 \%$ in Madrid, and $11.46 \%$ in the Basque Country (Table 1).

Table 1

ALLOCATION OF INTERVIEWS CONDUCTED TO PEOPLE FROM EXTREMADURA BY THE REGION THEY ARE SETTLED. 2011

\begin{tabular}{|l|r|r|r|r|}
\hline & \multirow{2}{*}{$\begin{array}{c}\text { Overall population } \\
\text { with roots from } \\
\text { Extremadura }\end{array}$} & \multirow{2}{*}{ \% population } & Sample size & \multirow{2}{*}{$\begin{array}{c}\text { (interviews } \\
\text { conducted) }\end{array}$} \\
\cline { 4 - 5 } Andalusia & 61,309 & 12.89 & 60 & 12.50 \\
\hline Catalonia & 136,461 & 28.68 & 140 & 29.17 \\
\hline Madrid & 219,644 & 46.17 & 225 & 46.88 \\
\hline Basque Country & 58,344 & 12.26 & 55 & 11.46 \\
\hline Total & 475,758 & 100 & 480 & 100 \\
\hline
\end{tabular}

The treatment of the data has two levels. First there is a descriptive analysis of the results. Then there is a correlation analysis for ordinal variables (Spearman's rank correlation coefficient $r h o$ ) and nominal variables (Pearson's contingency coefficient). With that statistical treatment, we intend to answer the questions proposed in the six hypotheses that guide this paper.

\section{RESULTS}

\subsection{Motivational Factors of Back-home Tourism}

Motivation $^{1}$ is the driving factor to determine the touristic role, and it relies on components such as age, previous tourism experiences, and status (Pearce, 1993). We consider in this paper that motivations related to relaxation, the search for quiet, or the search for nature are more typical of the touristic role than other motivations such as meeting fam-

1 See Castaño (2005) for a summary of some tourist typologies based on motivation and traveling expectations. 
ily and friends. We clustered the motivational panorama of the visits into three categories (Rubio \& Sánchez-Oro, 2013). Some respondents express aspects related to leisure, recreation, and contact with nature $(23.4 \%)$ as their main reason for the visit. We assign this group the most purely tourist role. We call these back-home tourist Type I. Others express that their reason to travel is their attachment to family and friends and their desire to meet them $(66.2 \%)$. In this case, the touristic focus is secondary. These would be back-home tourist Type II. The remaining $10.3 \%$ express other types of reasons. These would be countryman tourist Type III. Among these motivations are: following tradition, cheaper holidays, or devotion to the patron saint.

We will use these three categories as critical variables in our analysis, although more attention will be paid to the incidents found in types I and II because they are the most representative.

Table 1 matches the motivations we have been considering with the origin of the respondents. We found that leisure and recreation reasons stood out for those who live in Madrid and surrounding areas, followed by those from Andalusia. However, those living in Catalonia highlight the attachment to family and friends and their desire to meet them as the main reason to make the visit in much greater proportion. And those from the Basque country highlight only these motivations.

Table 2

REGION OF ORIGIN OF "BACK-HOME" TOURISTS TO EXTREMADURA AND STANDARDIZED REASONS FOR COMING. 2011

\begin{tabular}{|l|r|r|r|r|}
\hline \multirow{2}{*}{ Region } & \multicolumn{3}{|c|}{ Contingency table(Percentage by region) } & \multirow{2}{*}{ Typified reasons } \\
\cline { 2 - 5 } & $\begin{array}{c}\text { Leisure and } \\
\text { recreation }\end{array}$ & $\begin{array}{c}\text { Meeting relatives } \\
\text { and bonding. }\end{array}$ & \multicolumn{1}{c|}{ Other reasons } & \\
\hline Catalonia & $12.9 \%$ & $78.6 \%$ & $8.6 \%$ & $100.0 \%$ \\
\hline Andalusia & $22.0 \%$ & $74.6 \%$ & $3.4 \%$ & $100.0 \%$ \\
\hline Madrid & $36.0 \%$ & $48.2 \%$ & $15.8 \%$ & $100.0 \%$ \\
\hline Basque Country & & $100.0 \%$ & & $100.0 \%$ \\
\hline Overall sample & $23.4 \%$ & $66.2 \%$ & $10.3 \%$ & $100.0 \%$ \\
\hline
\end{tabular}

Source: Our own from ref. PRI08A0456 "Investigación sociológica sobre retornados y turistas paisanos en la neorrualidad"

\subsection{Back-home Tourists' Patterns: Expense, Length of Stay, and Other}

According to the level of spending (Table 3), presuming reliability, those who come for recreation are those who show a lower level, given that almost $45 \%$ of them declare to spend between $100-500 €$ during their stay (depending on the length of their stay) 
compared to those who claim other reasons. We might say that Type I countryman tourists are less wasteful than Type II, who do not associate their visits with the typical touristic reasons.

Table 3

DECLARED SPENDING ALLOCATED BY REASONS FOR THE VISIT. 2011. PERCENTAGES

\begin{tabular}{|c|c|c|c|c|c|}
\hline \multicolumn{6}{|c|}{ How much do you spend when you come to Extremadura? } \\
\hline & $100-500 €$ & $501-1000 €$ & $1500-2000 €$ & $\begin{array}{l}\text { More than } \\
2001 €\end{array}$ & Total \\
\hline $\begin{array}{l}\text { Countryman tourist } \\
\text { type I (Leisure and } \\
\text { recreation) }\end{array}$ & 44.9 & 31.8 & 14.0 & 9.3 & 100 \\
\hline $\begin{array}{l}\text { Countryman tourist } \\
\text { type II (Meeting } \\
\text { relatives and bonding) }\end{array}$ & 29.5 & 35.3 & 24.7 & 10.5 & 100 \\
\hline $\begin{array}{c}\text { Countryman tourist } \\
\text { type III (Other reasons) }\end{array}$ & 46.5 & 20.9 & 16.3 & 16.3 & 100 \\
\hline OVERALL SAMPLE & 34.8 & 33.0 & 21.3 & 10.8 & 100 \\
\hline
\end{tabular}

Source: Our own from ref. PRI08A0456 "Investigación sociológica sobre retornados y turistas paisanos en la neorrualidad"

In line with the spending, the length of stay in the region (Table 3) is also lower among those whose reasons are leisure and enjoyment. Of these, $62.3 \%$ stay one to two weeks in Extremadura, while there is a greater dispersion among back-home tourists Type II, as $46.3 \%$ of them stay longer than three weeks in Extremadura. In terms of the synthetic indicator "permanence," we can establish that on a scale of 0 to 1 , the level of permanence in the region for those seeking leisure and enjoyment is 0.43 , while for those seeking to meet friends and family it is 0.48 .

No matter the length of the stay, in all typologies considered, the place for fun and enjoyment (Table 4), as well as the place where they spend their money (Table 5), is mostly the village where they arrive. Even in the case of those who seek leisure and entertainment as the main reason to visit Extremadura, only 3.6\% refer to a bigger town to get what they need. 
Table 4

LENGTH OF STAY ALLOCATED BY REASONS FOR THE VISIT. 2011. HORIZONTAL PERCENTAGES

\begin{tabular}{|c|c|c|c|c|c|}
\hline \multicolumn{7}{|c|}{ How long do you usually stay in the village? } \\
\hline & One week & $\begin{array}{c}\text { Two } \\
\text { weeks }\end{array}$ & $\begin{array}{c}\text { Three } \\
\text { weeks }\end{array}$ & $\begin{array}{c}\text { More } \\
\text { than three } \\
\text { weeks }\end{array}$ & $\begin{array}{c}\text { Lenth } \\
\text { indicator }\end{array}$ \\
\hline $\begin{array}{c}\text { Countryman tourists type I } \\
\text { (Leisure and recreation) }\end{array}$ & 36.8 & 25.5 & 7.5 & 30.2 & 0.43 \\
\hline $\begin{array}{c}\text { Countryman tourist type II } \\
\text { (Meeting relatives and bonding) }\end{array}$ & 33.8 & 19.9 & 10.5 & 35.8 & 0.48 \\
\hline $\begin{array}{c}\text { Countryman tourists } \\
\text { type III (Other reasons). }\end{array}$ & 35.6 & 20.0 & 8.9 & 35.6 & 0.48 \\
\hline OVERALL SAMPLE & 34.7 & 21.3 & 9.6 & 34.5 & \\
\hline
\end{tabular}

Source: Our own from ref. PRI08A0456 "Investigación sociológica sobre retornados y turistas paisanos en la neorrualidad".

Table 5

USUAL LEISURE PLACES BY REASONS FOR THE VISIT. PERCENTAGES

\begin{tabular}{|c|r|r|r|r|}
\hline \multicolumn{6}{|c|}{ Where do you usually have fun during your visit to Extremadura? } \\
\hline & $\begin{array}{c}\text { In the villaje } \\
\text { you are staying }\end{array}$ & $\begin{array}{c}\text { Neighboring } \\
\text { villages }\end{array}$ & In town & Total \\
\hline $\begin{array}{c}\text { Countryman tourist type I } \\
\text { (Leisure and recreation) }\end{array}$ & 95.5 & 0.9 & 3.6 & 100 \\
\hline $\begin{array}{c}\text { Countryman tourist type II } \\
\text { (Meeting relatives and bonding) }\end{array}$ & 96.4 & 2.3 & 1.3 & 100 \\
\hline $\begin{array}{c}\text { Countryman tourists type III } \\
\text { (Other reasons). }\end{array}$ & 91.3 & 2.2 & 6.5 & 100 \\
\hline OVERALL SAMPLE & 95.7 & 1.9 & 2.4 & 100 \\
\hline
\end{tabular}

Source: Our own from ref. PRI08A0456 "Investigación sociológica sobre retornados y turistas paisanos en la neorrualidad" 
An important part of the spending for all these groups is made at restaurants. Those who express purely touristic reasons for their visit are the ones who most frequently make use of this service, perhaps due to the degree of mobility appropriate to fulfil their expectations. It is worth emphasizing the rate of frequency for countryman tourist Type II, which is the largest group.

Table 6

FREQUENCY OF RESTAURANT ATTENDANCE BY REASONS FOR THE VISIT. 2011. PERCENTAGES

\begin{tabular}{|c|r|r|r|r|}
\hline \multicolumn{2}{|l|}{ Activity carried out in Extremadura: restaurants } \\
\hline $\begin{array}{c}\text { Everyday } \\
\begin{array}{c}\text { Countryman tourists type I (Leisure and } \\
\text { recreation) }\end{array}\end{array}$ & Once in a while & Never & Total \\
\hline $\begin{array}{c}\text { Countryman tourist type II (Meeting relatives } \\
\text { and bonding) }\end{array}$ & 8.9 & 84.2 & 9.9 & 100 \\
\hline Countryman tourists type III (Other reasons). & 8.5 & 71.0 & 20.9 & 100 \\
\hline Total & 34 & 55.3 & 36.2 & 100 \\
\hline OVERALL SAMPLE & 7.6 & 322 & 89 & 445 \\
\hline
\end{tabular}

Source: Our own from ref. PRI08A0456 "Investigación sociológica sobre retornados y turistas paisanos en la neorrualidad".

We also must point out that the choice of accommodation during the stay in the region does not present significant differences between one type of visitor and another. In fact, $94.5 \%$ of countryman tourists stay in their own or relatives' homes, and only $3.6 \%$ stay in a rural hotel, boarding house, or hostel.

\subsection{Valuation of the "Extremadura Destination" According to Groups Type I and II}

As we have already pointed out, the degree of satisfaction from visiting Extremadura is very high. From the satisfaction indicator in Table 7, we can see that the overall level of satisfaction is 0.87 , with an even higher rate for Type I tourists. This is an indicator of a high degree of customer retention, superior to the satisfaction shown by countryman tourist Type II.

The ratings that different aspects of the Extremadura destination get from countryman tourists are "very good" or "good" in all aspects considered in this evaluation except for "access to employment," which is the resource that gets the lowest average rating. Figure 1 shows the data with combined values (very good + good). 
Table 7

SATISFACTION LEVEL FROM YOUR VISIT TO EXTREMADURA. 2011. PERCENTAGES

\begin{tabular}{|l|l|l|l|l|l|l|}
\hline & A lot & Quite & Regular & Little & Nothing & Indicator \\
\hline $\begin{array}{l}\text { Countryman tourists type I } \\
\text { (Leisure and recreation) }\end{array}$ & 56.8 & 40.5 & 2.7 & 0.0 & 0.0 & 0.89 \\
\hline $\begin{array}{l}\text { Countryman tourist type II } \\
\text { (Meeting relatives and bonding) }\end{array}$ & 51.8 & 43.4 & 4.5 & 0.3 & 0.0 & 0.87 \\
\hline OVERALL SAMPLE & 53.8 & 41.3 & 4.5 & 0.2 & 0.2 & 0.87 \\
\hline
\end{tabular}

Source: Our own from ref. PRI08A0456 "Investigación sociológica sobre retornados y turistas paisanos en la neorrualidad".

The quality of the recreational activities offered in the villages is the most valued service in both groups. Type II countryman tourists show the highest valuation of recreational services, as $88 \%$ of them hold them in very high regard. Therefore, they have a festive-ludic motivation.

For the other services, the general ratings are above 50\% except for access to employment, which gets a very low valuation. Given that the length of the visits is varied, and depending on their duration (many of the visitors are already retired), there is a tendency to value more objectively the aspects they use most or that they know best such as health, social, or cultural services.

A close examination of these evaluations will allow us to sort out their innermost clues. Cultural activities are the main touristic attraction for many counties and villages of the region. The ratings linger very close to 0.7 in the indicator. It is interesting to note that for countryman tourists, the "fair" and "bad" ratings get a relatively high percentage of $37.8 \%$ for Type I and $35.5 \%$ for Type II. These figures should raise awareness about it and foster a search for ways to improve the cultural offer and to adapt it to the expectations of countryman tourists. 
Figure 1

RATING OF DIFFERENT ASPECTS OF THE "EXTREMADURA TOURISTIC DESTINATION." CONJOINED PERCENTAGES FOR "VERY GOOD + GOOD" CATEGORIES

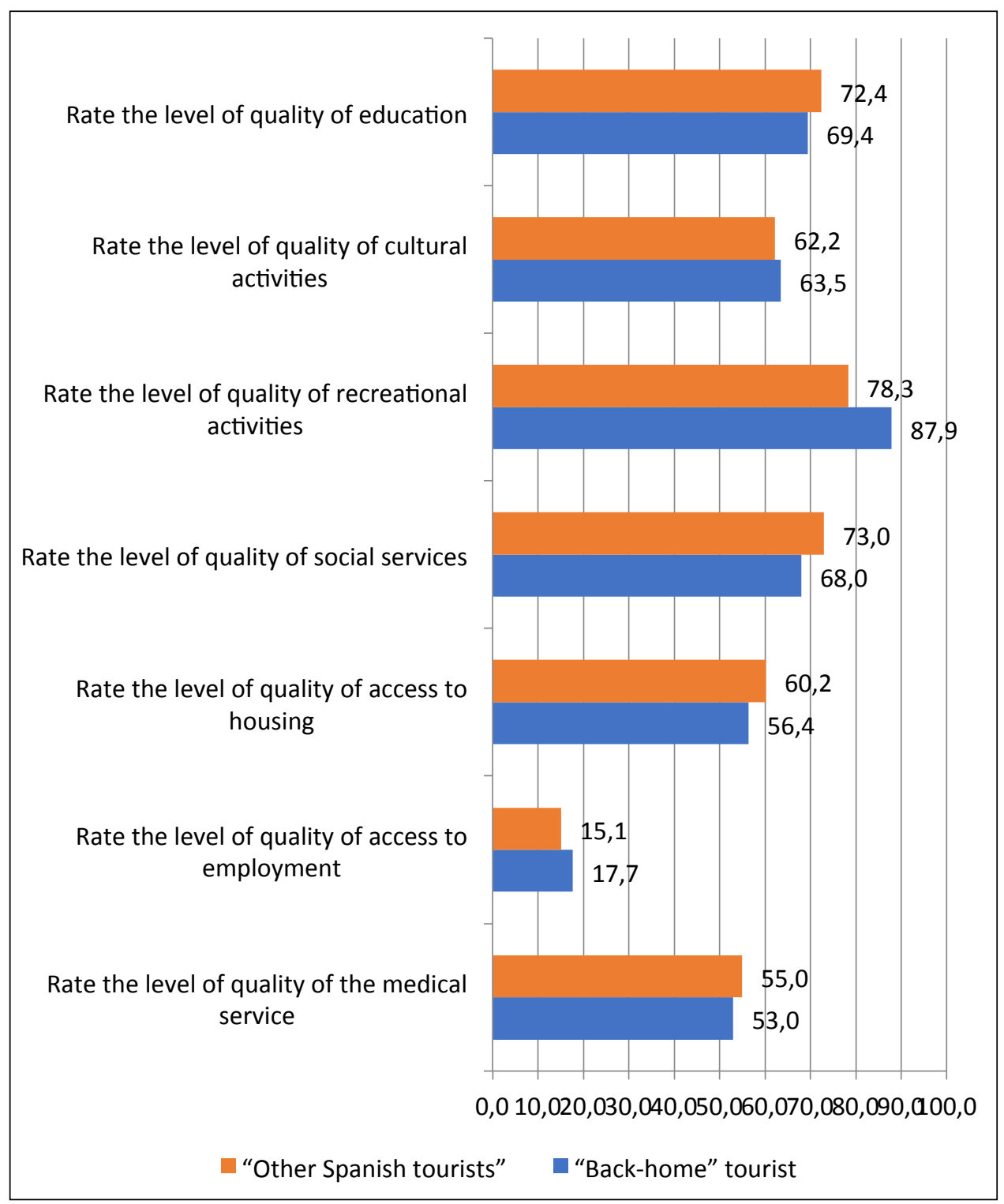

Source: Our own from ref. PRI08A0456 "Investigación sociológica sobre retornados y turistas paisanos en la neorrualidad". 
Table 8

QUALITY LEVEL OF CULTURAL ACTIVITIES ALLOCATED BY REASONS FOR THE VISIT. HORIZONTAL PERCENTAGES. RATING INDICATOR (0=VERY BAD,1=VERY GOOD). 2011

\begin{tabular}{|l|l|l|l|l|l|l|}
\hline & Very good & Good & Even & Bad & Very bad & Indicator \\
\hline $\begin{array}{l}\text { Countryman tourist type I } \\
\text { (Leisure and recreation) }\end{array}$ & 11.2 & 51.0 & 33.7 & 4.1 & 0.0 & 0.67 \\
\hline $\begin{array}{l}\text { Countryman tourist type II } \\
\text { (Meeting relatives and bonding) }\end{array}$ & 9.9 & 53.6 & 30.0 & 5.5 & 1.0 & 0.66 \\
\hline
\end{tabular}

Source: Our own from ref. PRI08A0456 "Investigación sociológica sobre retornados y turistas paisanos en la neorrualidad".

As shown in Table 9, recreational activities are very important for these two subgroups - not only the quantity but also their quality. For countryman tourists, their quality is above the rest of the services they evaluate in this section. This is very positive for the sector, as only $21.7 \%$ said that it was fair or bad.

Table 9

QUALITY LEVEL OF RECREATIONAL ACTIVITIES ALLOCATED BY REASONS FOR THE VISIT. HORIZONTAL PERCENTAGES. RATING INDICATOR (0 =VERY BAD.1=VERY GOOD). 2011

\begin{tabular}{|l|l|l|l|l|l|l|}
\hline & Very good & Good & Even & Bad & Very bad & Indicator \\
\hline $\begin{array}{l}\text { Countryman tourist type I } \\
\text { (Leisure and recreation) }\end{array}$ & 30.9 & 47.4 & 19.6 & 2.1 & .0 & 0.77 \\
\hline $\begin{array}{l}\text { Countryman tourist type II } \\
\text { (Meeting relatives and bonding) }\end{array}$ & 28.2 & 59.7 & 11.1 & .7 & .3 & 0.79 \\
\hline
\end{tabular}

Source: Our own from ref. PRI08A0456 "Investigación sociológica sobre retornados y turistas paisanos en la neorrualidad".

Social services (benefits for old people, children, youth, etc.) are also highly regarded by these groups, as shown by the average indicator 0.7 . These services are important for both groups and a leading factor for customer retention as well as for a future decision to return. 
Table 10

QUALITY LEVEL OF SOCIAL SERVICES ALLOCATED BY REASONS FOR THE VISIT. HORIZONTAL PERCENTAGES. RATING INDICATOR (O VERY BAD.1VERY GOOD). 2011

\begin{tabular}{|c|r|r|r|r|r|r|}
\hline \multicolumn{7}{|c|}{ Rate the quality of social services } \\
\hline & Very good & Good & Even & Bad & Very bad & Indicator \\
\hline $\begin{array}{c}\text { Countryman tourist type I } \\
\text { (Leisure and recreation) }\end{array}$ & 13.8 & 59.6 & 22.3 & 4.3 & 0.0 & 0.71 \\
\hline $\begin{array}{c}\text { Countryman tourist type II } \\
\text { (Meeting relatives and bonding) }\end{array}$ & 14.3 & 53.7 & 24.4 & 5.6 & 2.1 & 0.68 \\
\hline
\end{tabular}

Source: Our own from ref. PRI08A0456 "Investigación sociológica sobre retornados y turistas paisanos en la neorrualidad".

Medical services, which are closely linked to social services, get an acceptable rating in both groups. We have already noted the importance of these services for both groups who look for these benefits in their destinations, and they are sometimes key in their final choice of settlement. Keep in mind that the evaluations have been based on a comparison with the attention they get in the autonomous communities where they live.

Table 11

QUALITY LEVEL OF MEDICAL SERVICES ALLOCATED BY REASONS FOR THE VISIT. HORIZONTAL PERCENTAGES. RATING INDICATOR (O VERY BAD.1VERY GOOD). 2011

\begin{tabular}{|l|r|r|r|r|r|r|}
\hline \multicolumn{1}{|l|}{ Rate the level of quality of the medical service } \\
\hline & Very good & Good & Even & Bad & Very bad & Indicator \\
\hline $\begin{array}{l}\text { Countryman tourists type I } \\
\text { (Leisure and recreation) }\end{array}$ & 8.8 & 46.1 & 32.4 & 8.8 & 3.9 & 0.62 \\
\hline $\begin{array}{l}\text { Countryman tourist type II } \\
\text { (Meeting relatives and bonding) }\end{array}$ & 6.7 & 46.2 & 33.1 & 10.4 & 3.7 & 0.61 \\
\hline
\end{tabular}

Source: Our own from ref. PRI08A0456 "Investigación sociológica sobre retornados y turistas paisanos en la neorrualidad".

Figure 2 gathers all scores of the valuation indicator given to the different services in Extremadura. The first bar reflects the average rating (0.65), which is quite high. This score would be even higher if we disregarded the value that takes the lowest score (employment), which is the least relevant for the loyalty of countryman tourism to rural areas. Dismissing employment, the average valuation increases to 0.69. 
Figure 2

INDICATORS OF EVALUATION OF THE QUALITY OF SERVICES IN EXTREMADURA BY “COUNTRYMAN" TOURISTS. RATING INDICATOR (0=VERY BAD; 1=VERY GOOD)

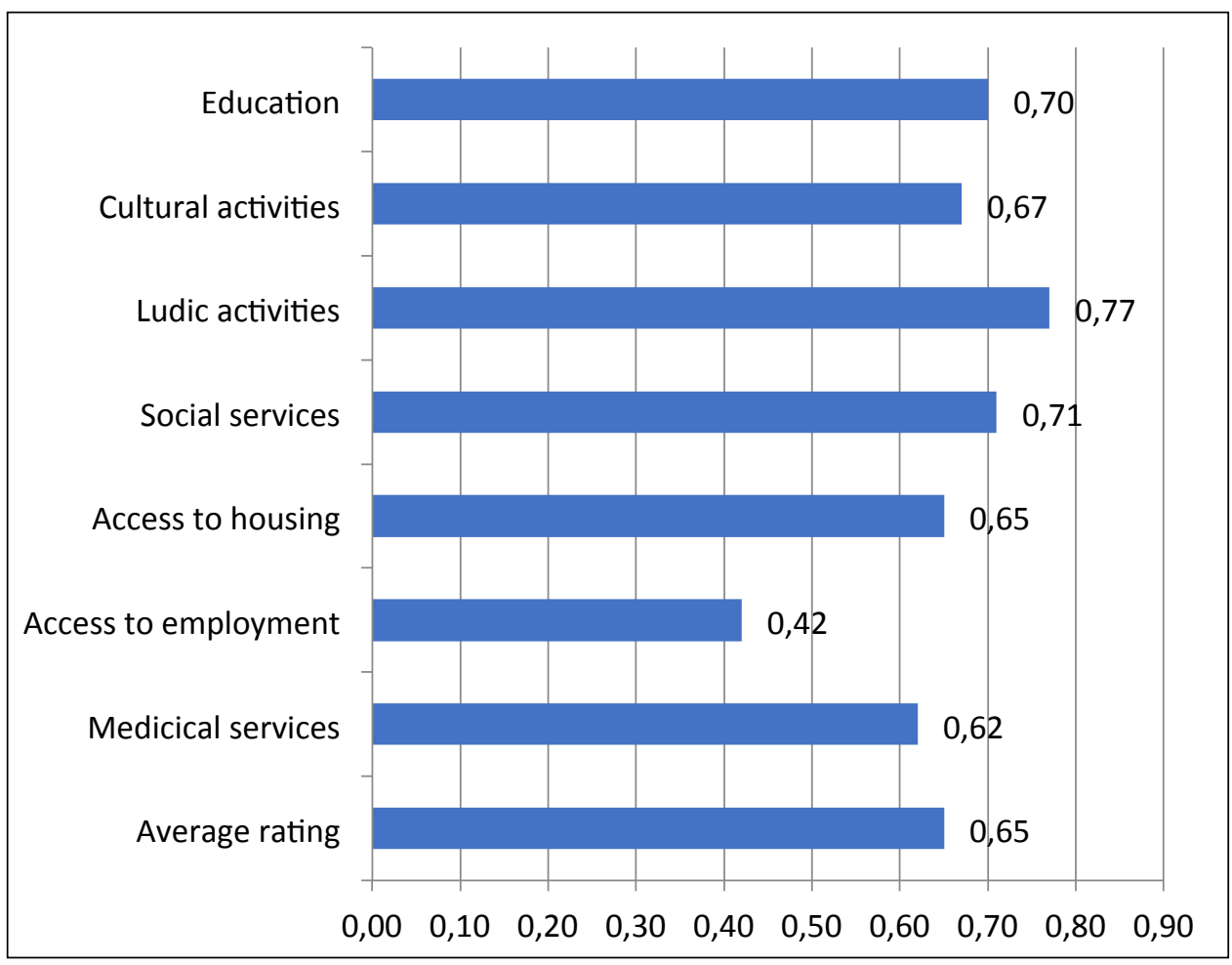

Source: Our own from ref. PRI08A0456 "Investigación sociológica sobre retornados y turistas paisanos en la neorrualidad".

\subsection{Comparative Valuation of the Rural Environment of Extremadura by "Coun- tryman" Tourists Type I and II}

Table 12 shows that the opinion countryman tourists have about the general situation of villages in Extremadura is that it is good or very good. This positive appraisal of the rural world is somewhat lower in the case of countryman tourists Type I, given that this indicator for them reaches only 0.67 . 
Table 12

OPINION ABOUT THE GENERAL SITUATION OF VILLAGES AND RURAL AREAS ALLOCATED BY REASONS FOR THE VISIT. HORIZONTAL PERCENTAGES

\begin{tabular}{|c|r|r|r|r|r|r|}
\hline \multicolumn{6}{|c|}{ Reasons for the visit and opinion about the general situation of villages and rural areas } \\
\hline & Very good & Good & Even & Bad & Very bad & Indicator \\
\hline $\begin{array}{c}\text { Countryman tourists type I } \\
\text { (Leisure and recreation) }\end{array}$ & 19.3 & 50.5 & 27.5 & 1.8 & .9 & 0.67 \\
\hline $\begin{array}{c}\text { Countryman tourist type II } \\
\text { (Meeting relatives and bonding) }\end{array}$ & 16.8 & 58.4 & 22.9 & 1.9 & .0 & 0.70 \\
\hline $\begin{array}{c}\text { Countryman tourist } \\
\text { type III (Other reasons). }\end{array}$ & 14.6 & 50.0 & 33.3 & 2.1 & .0 & 0.62 \\
\hline OVERALL SAMPLE & 17.1 & 55.7 & 25.1 & 1.9 & .2 & 0.68 \\
\hline
\end{tabular}

Source: Our own from ref. PRI08A0456 "Investigación sociológica sobre retornados y turistas paisanos en la neorrualidad".

The valuation of the rural world of Extremadura, compared to other regions they know, is less positive. According to these informants, the rural world of Extremadura would be worse off than that from the places where they are currently settled. However, we should state that in both cases, Extremadura and their place of origin, the indicator is a bit over 0.5 for the two groups. We can also outline that some informants believe that the situation of rural Extremadura compared to the place of origin is bad or very bad $-9.2 \%$ in the case of countryman tourists and $12.1 \%$ in the case of other tourists.

\subsection{Perception of Extremadura, or Collective Imaginary, in Both Types of "Coun- tryman" Tourists}

The process of building the image of a certain tourist destination has been described by different authors. Castaño (2005, p. 116) emphasizes Reynold's (1965) description, which defines this process as a mental construction based on "a few impressions chosen from the information flow about a certain destination and a lot of information about the destination itself." For a classic tourist, the sources of information would be promotional literature (travel brochures, specific advertising, posters), the opinions of others (family, friends, travel agents), and the media (specialized magazines, newspapers, books, Internet, TV; Gómez, 2016).

In the case we are studying, visitors native to the region confronted a battery of concepts. We can infer that for countryman tourists, the image of Extremadura is associated with a series of beliefs that we synthesize in Figure 3. Their main image is the prevalence of a "healthy" environment. Therefore, the main identifying value of the destination-region for this group is the environment (Assaker, Vinzi, \& O’Connor, 2011). 
Figure 3

VALUES “COUNTRYMAN” TOURISTS ASSOCIATE TO THE IMAGE OF EXTREMADURA. PERCENTAGE

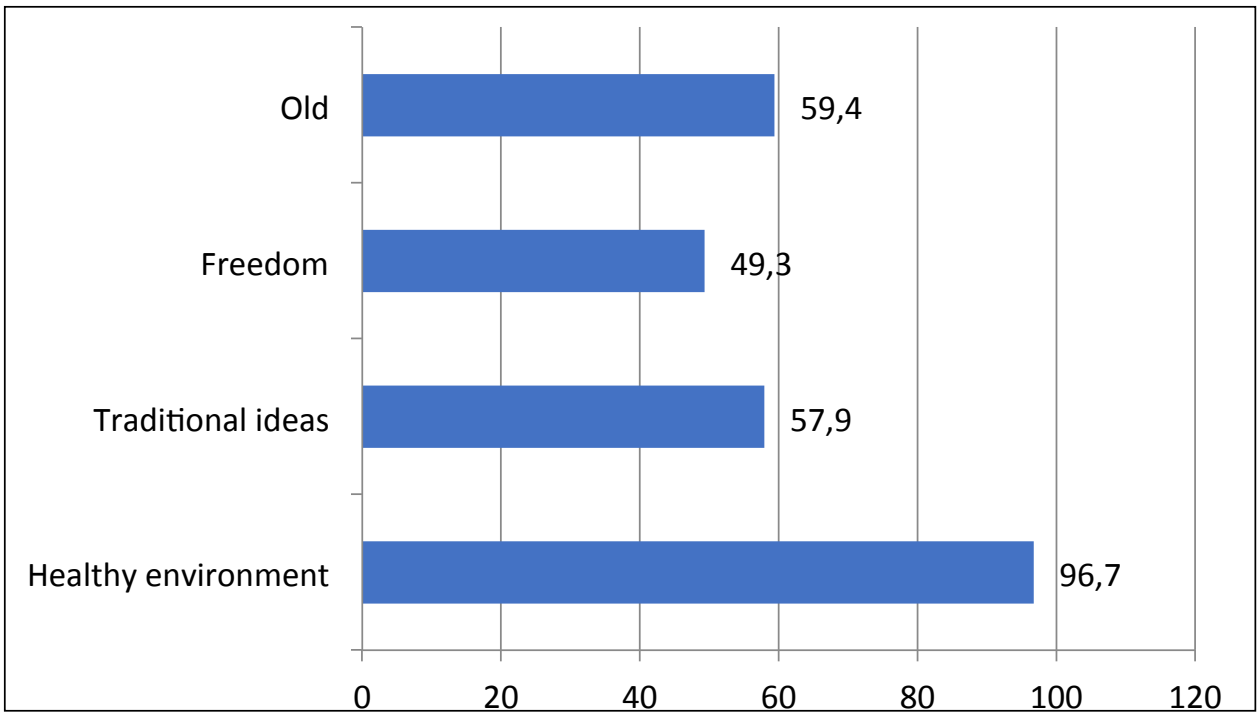

Source: Our own from ref. PRI08A0456 "Investigación sociológica sobre retornados y turistas paisanos en la neorrualidad".

However, it is necessary to specify some differentiating details among the types of countryman tourists. Regarding the dilemma of "old age vs. youth," around six out of every 10 countryman tourists of these two types identify the regional rural environment with old age, and only two relate it to youth.

Table 13

OLD VS. YOUTH. WHAT DOES THE RURAL WORLD OF EXTREMADURA IDENTIFY WITH? ALLOCATED BY REASONS FOR THE VISIT. 2011

\begin{tabular}{|l|c|c|c|c|}
\hline & Old & Irrelevant & Youth & Total \\
\hline $\begin{array}{l}\text { Countryman tourists type I (Leisure and } \\
\text { recreation) }\end{array}$ & 59.4 & 18.8 & 21.7 & 100 \\
\hline $\begin{array}{l}\text { Countryman tourist type II (Meeting relatives } \\
\text { and bonding) }\end{array}$ & 56.3 & 22.8 & 20.9 & 100 \\
\hline OVERALL SAMPLE & 58.3 & 20.7 & 21.0 & 100 \\
\hline
\end{tabular}

Source: Our own from ref. PRI08A0456 "Investigación sociológica sobre retornados y turistas paisanos en la neorrualidad". 
Around $50 \%$ of countryman tourists identify the rural world of the region with the idea of "freedom" in spite of the fact that traditionally rural life has been associated with social control and group identity versus individuality. However, almost $30 \%$ of countryman tourists still associate the rural world of Extremadura with "social control."

Table 14

SOCIAL CONTROL VS. FREEDOM. WHAT DOES THE RURAL WORLD OF EXTREMADURA IDENTIFY WITH? ALLOCATED BY REASONS FOR THE VISIT. (N: 296)

\begin{tabular}{|l|r|r|r|r|}
\hline & Social Control & Irrelevant & Freedom & Total \\
\hline $\begin{array}{l}\text { Countryman tourists type I } \\
\text { (Leisure and recreation) }\end{array}$ & 28.2 & 22.5 & 49.3 & 100 \\
\hline $\begin{array}{l}\text { Countryman tourist type II } \\
\text { (Meeting relatives and bonding) }\end{array}$ & 25.9 & 22.2 & 51.9 & 100 \\
\hline
\end{tabular}

Source: Our own from ref. PRI08A0456 "Investigación sociológica sobre retornados y turistas paisanos en la neorrualidad".

Likewise, $58 \%$ of countryman tourists also identify Extremadura with traditional ideas. However, $20 \%$ identify the rural areas with a "new mentality."

Table 15

TRADITIONAL IDEAS VS. NEW MENTALITY. WHAT DOES THE RURAL WORLD OF EXTREMADURA IDENTIFY WITH? ALLOCATED BY REASONS FOR THE VISIT. 2011

\begin{tabular}{|l|r|r|r|r|}
\hline & Traditional Ideas & Indiferent & New mentality & Total \\
\hline $\begin{array}{l}\text { Countryman tourists type I } \\
\text { (Leisure and recreation) }\end{array}$ & 57.9 & 21.1 & 21.1 & 100 \\
\hline $\begin{array}{l}\text { Countryman tourist type II } \\
\text { (Meeting relatives and bonding) }\end{array}$ & 53.3 & 19.5 & 27.1 & 100 \\
\hline
\end{tabular}

Source: Our own from ref. PRI08A0456 "Investigación sociológica sobre retornados y turistas paisanos en la neorrualidad"

In broad terms, we can state that countryman tourists get an ambivalent image from their experiences in their visits to the region. Most of them convey the idea of a healthy environment mixed with the sensation of social control.

Also, the identification of rural areas with traditional ideas and the aging of the population lasts in more than $50 \%$ of respondents. 
Although there is little difference between the two types of tourists considered, Type I tourists more often notice the negative aspects of the rural environment, such as aging and the traditional mentality, while Type II tourists tend to emphasize the level of freedom.

\section{DISCUSSION}

Based on the respondents' stand about spending, visit satisfaction, and their opinions on the rural world of Extremadura, we have performed a covariation analysis using Spearman's rho due to the ordinal nature of these variables. Furthermore, there is an analysis of the classification variables of the informants with reference to the type of tourism they perform. Because this deals with nominal variables, we use Pearson's contingency coefficient.

From Table 17, we can infer that Hypothesis 1 is only partially supported because the covariation is positive but very close to zero. The term that correlates more clearly is "Reasons for the visit and frequency in the restaurants" ( $r h o=0.128)$. Hypothesis 2 , referring to back-home tourism based on motivations, correlates negatively with fragmentary aspects of the satisfaction they get from services in the places they visit. The hypothesis is supported in the sense that there is a negative correlation between the satisfaction these tourists get from cultural, medical, educational, or leisure activities and the type of tourism they develop. Despite the negative valuation, visitors will continue doing this kind of tourism. Considering overall satisfaction, there is a neutral correlation $(r h o=0)$.

Hypothesis 3 is relative to the collective image that these back-home visitors have. Their approaches to backwardness and social control in the villages they visit are not factors that influence their touristic practices. This is probably because, regardless of how they perceive these villages, they don't feel concerned by the problem.

Table 16

COVARIATION OF DEPENDENT VARIABLES BASED ON THE SAMPLE DATA

\begin{tabular}{|l|r|r|r|}
\hline \multicolumn{1}{|c|}{ Spearman rho correlation } & \multicolumn{1}{c|}{ Coefficient } & \multicolumn{1}{c|}{ Error } & \multicolumn{1}{c|}{ Sig } \\
\hline Spending & & & \\
\hline Qualified reasons \& Expense & 0.082 & 0.05 & 0.083 \\
\hline Qualified reasons \& time spent in the village & 0.041 & 0.047 & 0.39 \\
\hline Qualified reasons \& fun place & 0.028 & 0.054 & 0.54 \\
\hline Qualified reasons \& restaurant attendance & 0.128 & 0.046 & 0.007 \\
\hline Qualified reasons \& bars attendance & 0.072 & 0.047 & 0.127 \\
\hline
\end{tabular}




\begin{tabular}{|l|r|r|r|}
\hline \multicolumn{1}{|c|}{ Spearman rho correlation } & \multicolumn{1}{c|}{ Coefficient } & \multicolumn{1}{c|}{ Error } & \multicolumn{1}{c|}{ Sig } \\
\hline Satisfaction with the visit & & & \\
\hline $\begin{array}{l}\text { Qualified reasons \& Level of satisfaction with you revisits to } \\
\text { Extremadura }\end{array}$ & 0.021 & 0.046 & 0.644 \\
\hline Qualified reasons \& quality level of cultural activities & -0.056 & 0.049 & 0.242 \\
\hline Qualified reasons \& quality of recreational activities & -0.078 & 0.051 & 0.103 \\
\hline Qualified reasons \& quality of social services & -0.025 & 0.05 & 0.61 \\
\hline Qualified reasons \& quality of medical service & -0.044 & 0.05 & 0.354 \\
\hline Opinion aboutvillages & & & 0.877 \\
\hline $\begin{array}{l}\text { Qualified reasons \& opinion on the general situation of } \\
\text { the villages and rural areas }\end{array}$ & 0.007 & 0.048 & \\
\hline Image of the rural world & & & -0.64 \\
\hline $\begin{array}{l}\text { Qualified reasons \& Identifying Extremadura as Old vs. } \\
\text { Youth. }\end{array}$ & -0.026 & 0.056 & 0.217 \\
\hline $\begin{array}{l}\text { Qualified reasons \& Identifying Extremadura about Social } \\
\text { Control vs. Freedom. }\end{array}$ & -0.072 & 0.059 & \\
\hline $\begin{array}{l}\text { Qualified reasons \& Identifying Extremadura with } \\
\text { Traditional Ideas vs. New mentality }\end{array}$ & 0.071 & 0.056 & 0.2 \\
\hline
\end{tabular}

Source: Our own from ref. PRI08A0456 "Investigación sociológica sobre retornados y turistas paisanos en la neorrualidad"

Hypothesis 4, which is related to the places where these tourists are permanently settled, correlates positively to the motivations of countryman tourists. We verified that this correlation is very high with regard to the place of origin of the interviewees $(C=0.492)$ even when they are sorted by autonomous communities (Basque Country, Catalonia, Madrid, Andalusia; $C=0.365$ ). A plausible explanation of this phenomenon could be that different tourists' motivations are linked to the regions where they live. Certain features of these tourists, especially their level of income and their expectations, are different depending on the region they come from, although all of them have Extremadura roots. Table 19 gives details on two variables, origin and motivation.

Hypothesis 5 focuses on the correlation between the touristic motivation of back-home tourists and sociological variables such as studies, age, and number of people travelling. The results are meaningful but not very relevant. This hypothesis is supported in the sense that $\mathrm{C}$ takes the value 0.2 . Given that $\mathrm{C}=1$ is the highest correlation, this outcome is low.

Finally, Hypothesis 6 stated that variables such as gender and marital status do not come into play in tourists' motivations. In this case, we can observe that gender has no relevance to this type of tourism, and marital status has only a little ${ }^{2}$. This is a variable that does not adequately reflect the setting "travelling couple."

2 Also see Basu (2017). 


\section{Table 17}

\section{COVARIATION OF THE SOCIOLOGICAL VARIABLES FROM THE PEARSON CONTINGENCY COEFFICIENT $(C)$}

\begin{tabular}{|l|r|r|}
\hline Contingency coefficient & Coeff. & Sig. \\
\hline Qualified reasons * Current residence & 0.492 & 0 \\
\hline Qualified reasons * Region & 0.365 & 0.265 \\
\hline $\begin{array}{l}\text { Qualified reasons * How many people travel with you (you } \\
\text { included) }\end{array}$ & 0.259 & 0.001 \\
\hline Qualified reasons * Studies & 0.235 & 0.008 \\
\hline Qualified reasons * Age by intervals & 0.218 & 0.048 \\
\hline Qualified reasons * Marital status & 0.179 & 0.872 \\
\hline Qualified reasons * Gender & 0.024 & \\
\hline
\end{tabular}

Source: Our own from ref. PRI08A0456 "Investigación sociológica sobre retornados y turistas paisanos en la neorrualidad".

Table 18

\section{QUALIFIED REASONS REGION WHERE THE INTERVIEWEES ARE CURRENTLY SETTLED}

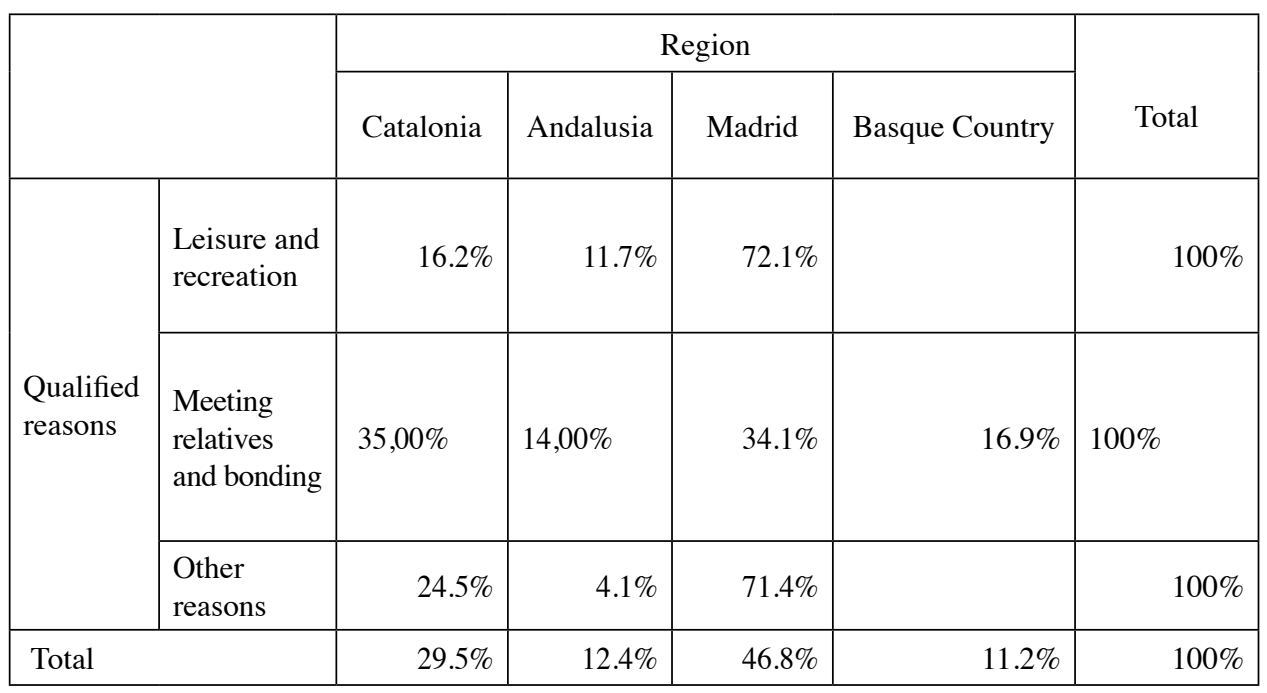

Source: Our own from ref. PRI08A0456 "Investigación sociológica sobre retornados y turistas paisanos en la neorrualidad". 


\section{OUTCOMES}

This paper aimed to describe back-home travelers according to their motivations, which helped to determine whether it is truly "back-home" tourism. After carrying out this classification, we focused on describing the main spending patterns of these kinds of visitors and some intangible considerations that might explain their demeanor.

The correlational analysis allowed us to clear the six hypotheses raised in the introduction. The main conclusion of these covariations of variables is that the one that better explains the travelling motivation for the countryman tourist is the locality and autonomous community in which they currently live. This conclusion does not surprise us due to the fact that socialization processes in Spain have special features in Catalonia and Basque Country or in Madrid and Andalusia, and this affects migrants from Extremadura, who left one day to live in those regions, and their families.

On the other hand, it is not a coincidence that groupings occur based on residence locations that share similar characteristics and visions of the world because the emigration processes that are in the base of this grouping are not random. They follow patterns of kinship and proximity, and this determines the patterns of these groups.

Contrary to what the conventional literature maintains, in this case, sociological variables do not play a key role in the motivation of this type of tourist, as we see from the verification of Hypotheses 5 and 6 . There are still some interesting future lines of analysis, which are only sketched by this paper.

\section{ACKNOWLEDGMENTS}

The presentation of this paper has been possible thanks to the funding made by the Regional Government of Extremadura and the European Regional Development Fund ERFD, reference GR15126 to the research group DELSOS.

\section{REFERENCES}

ASSAKER, G., VINZI, V.E. and O'CONNOR, P. (2011): «Examining the effect of novelty seeking, satisfaction, and destination image on tourists' return pattern: A two factor, non-linear latent growth model», Tourism Management, vol. 32 (4), pp. 890-901.

BARROS, C.P. and ASSAF, A.G. (2012): «Analyzing tourism return intention to an urban destination», Journal of Hospitality and Tourism Research, vol. 36 (2), pp. 216-231.

BASU, P. (2017): Roots-tourism as return movement: Semantics and the Scottish diaspora. Emigrant Homecomings, 2017 - manchesterhive.com.

CASTAÑO, J. (2005): Psicología Social de los viajes y del turismo. Madrid, Thomson.

DO VALLE, P.O., CORREIA, A. and REBELO, E. (2008): «Determinants of tourism return behavior», Tourism and Hospitality Research, vol. 8 (3), pp. 205-219.

DOMÍNGUEZ ARCOS, F. (2011): «Los viajeros del siglo XXI: La repercusión del público inmigrante en la industria turística española», Revista de Investigación en Turismo y Desarrollo Local, Vol. 4 (9). 
DUVAL, D.T. (2002): «The return visit-return migration connection», in Tourism and migration, Dordrecht, Springer, pp. 257-276.

GARCÍA GARCÍA, Y., BLANCO GREGORY, R. and PÉREZ RUBIO, J.A. (2013): «The "countryman tourism" in rural areas: The case of Extemadura (Spain) », in Methods and Analysis on Tourism and Environment, pp. 135-146.

GARCÍA GONZÁLEZ, J., CEBRIÁN ABELLÁN, F. and PANADERO MOYA, M. (2008): «El turismo de segunda residencia en el interior peninsular», Scripta Nova. Revista Electrónica de Geografía y Ciencias Sociales, vol. 12, nº 270 (94).

MARCOS GÓMEZ, C.E. (2016): La televisión de proximidad en Extremadura: Sostenibilidad e identidad. Tesis Doctoral. Universidad de Extremadura.

PEARCE, P.L. (1993): «Fundamental of tourist motivation», in Tourism research: Critiques and challenges", London: Routledge, pp. 113-134.

PÉREZ RUBIO, J. and GARCÍA GARCÍA, Y. (2005): «El turismo rural en Extremadura. El caso del turismo "paisano"», Revista Española de Estudios Agrosociales y Pesqueros, n $\mathrm{n}^{\circ} 206$, pp. 87-111.

PÉREZ RUBIO, J., SÁNCHEZ-ORO, M. and GARCÍA GARCÍA, Y. (2013): Turistas paisanos, retornados y mayores. Tres categorías a tener en cuenta en el futuro de las comunidades rurales. Cáceres, Universidad de Extremadura.

PEVELING, B. (2009): «Tourism of return as cultural reserve: Jewish pilgrims from France on their way to Djerba and back», Zeitschrift fur Ethnologie, vol. 134 (2), pp. 171-187.

RANDRIAMBOARISON, R., RASOAMANAJARA, F. and SOLONANDRASANA, B. (2013): «Tourism return frequency demand in Madagascar», Tourism Economics, vol. 19 (4), pp. 943-958.

MORALES, R., SÁNCHEZ, M., GIJÓN-CRUZ and CONTRERAS, C. (2009): «Impacto del turismo nostálgico y las remesas familiares en el desarrollo de la comunidad rural oaxaqueña», Migración y Desarrollo, ${ }^{\circ}$ 12, 69-88.

RUIZ OLABUÉNAGA, J. (1994): “Ocios y estilos de vida”, en V Informe Sociológico sobre la situación social de España, Madrid, Fundación FOESSA.

VOLO, S. and GIAMBALVO, O. (2008): «Tourism statistics: Methodological imperatives and difficulties. The case of residential tourism in Island communities», Current Issues in Method and Practice, vol. 11 (4), pp. 369-380.

WTO [WORLD TOURISM ORGANIZATION] (2008): International recommendations on tourism statistics. Department of social and economic affairs. Statistics Division. Estudios de métodos Serie M , Madrid/Nueva York, nº. 83/Rev.1.

YAGÜE PERALES, R. (2002): «Rural tourism in Spain», Annals of Tourism Research, vol. 29 (4), pp. 1.101-1.110. 
